\section{A TYPHOID CARRIER ON SHIPBOARD}

\section{IVILBUR A. SAWYER, M.I).}

Director of the Burent of the Hyglonfe Iaboratory of the Califoruin State Board of Henlth

BWRKELKY, CAL.

An investigation just completed by the California State Board of Health has traced twenty-seven cases of typhoid among sailors to a carrier in the erew of a lumleer steamer. Four of the patients succumbed to the disease. This typhoid carricr is unique among those already reported inasmuch as he was a member of a ship's crew and infected a large number of his companions without having anything to do with the handling of their food. 'The danger from typhoid on this ship was so well known among satilors that the vessel wis called the "fever ship" and it was difficult to scenre clesirable men for the crew.

For three and a half years it has been noticer? at the United States Marine Hospital in San Francisco that a large part of all the typhoid cases las come from the steamship Acme, a vessel carrving lumber l'oum 1Fumboldt Bay, nsually from Arcata, to San Francisco Bay and sometimes to Sun Pedro, the port of Los Angeles. This observation was reported to the State Boird -of. Health and the Health Departnent of Sun Franciseo. An investigation, carried on by the latter, brought to light evidence pointing to a member of the erew as a carrier. This man, H. O., was investigated during two weeks in the City and County Hospital in San Francis(c), but was discharged on Dee. 15, 1911, after the city hacteriologist had reported that the blood gave negative Widal tests and that typhoid bacilli could not at that time be demonstrated in the stools.

The investigation by the city showed that the solution of this problem involved work in other cities. 'The State Board of Health was notified of this fact and immediately assigned the investigation to the Division of Epidemiology of the Bureau of the Hyrienic Laboratory. The director' of the bureau began work on the problem on Dec. 28, 1911.

The Acme takes fucl oil in San Francisco but discharges cargo in Oakland. No passengers are carried, and there are usually only twenty-one men employed on hoard. These are the captnin, first mate, second rlite. (hicf engineer, assistant engineer, two firemen, one cook, one waiter, and twelve seamen.

Sanitary surveys showed that the ship was on the whole no less sanitary than most vessels of her kint. There was evidence of recent alterations made by the owners in their attempt to check the series of typhoicl cases by making the vessel more hygienic. The messroom for the offieers was elean and attractive. The crew took the food which was set ont for them and nte it sitting on the cargo. The galley was not so clean as is desirable. Disles were rashed in lot water in a small tank heated by stcan coils.

'The forecastle housed twelve men in very close quarters. There were three tiers of bunks and very little unoccupied space. The air conditions had recently been rendered less objectionalle by the placing of a ventilator through the deck overhend. At the first inspection the sailors' water-closet was in a filthy state and sugrested opportunity for the spread of infection by flies. Before the investigation had terminated conditions had been greatly improved by the replacing of the bowl, the installation of a system of constant flushing with seawater, and the cementing of the floor. The danger of conveyance of infection by flies was very slight while the ship was at sea and practically free from them, but considerable when the vessel was tied at fly-infested wharves.

The introduction of typhoid bacilli to the ship in the-food-supply could be almost entirely ruled out. No freslı milk was taken aboard, condensed milk being used. Fresh regetables, such as lettuce, radishes, celery, and onions, were enten raw by the erew, but all the food except meat was purchased exclusively in San Francisco. Other ships buying in the same market were free from typlosid.

The drinking-water supply for the galley was taken throngh a pipe and lancet from a large closed iron tank. Near the forecastle was a new eorered barrel from which the erew obtained water through a fancet for drinking and wnshing. Near the deck-house was an old cask which had escaped destruction at the time the alterations were made, when the other water-containers were replaced. It lay on its side, and water was obtained from it by dipping through a small sifuare loole with a common drinking-erp. It is apparent that menbers of the erew reaching into the dark barrel would wet their loands and contmininate the water. 'This cask was called the officers' cask. It supplied water for the officers' talle and for any members of the crew who foum it convenient to drink from it. 'The officers' cask has recently been thrown overboard and has been succeeded by a small barrel with a faucet.

Samples were taken from each water-supply and were examined for colon bacilli. All the examinations were negative except one of two tests made of samples taken from the officers' ensk. A portion of this one sample of water showing colon lacilli was jneubated in lactose bile and later plated on Endo medimm, but typhoid hacilli could not be demonstrated. Possibly the results would have been different if the officer's' cask had not been f'reshly filled shortly before each examination.

In orler to eliminate as far as possible infection from unknown water-supplies the owner's had specified for some time past that all the drinking-water should be taken aboard in San Francisco. This 'meant that the ollicer's' cask might receive contamination for nearly a week between fillings. Limiting the water-supply to a single sufe source did not prevent further cases from dercloping.

It was evictent that there were several methods by which typhoid bacilli might he realily distributed by one nember of the erew to the others. 'The infection could be spreat by contamination of the food during preparation, by pollution of the oflicers' rask. by soiling of the hands of the erew in the crowded foreenstle or the insanitary toilet, or by transference of infections material by flies from the toiket to the food-supply. The contamination of the officers' cask secmed to explain most satisfactorily the possible distribution of typhoil Incilli from a carrier to the majority of the cases.

Inquiry showed that the men aid not frequent any particular boarding-house or saloon in Areata or San Frnneisco. They ate on board ship during their term of service and most of them hard never gone ashore in Arcata. In San Frnnciseo they scattered about town as did the sailors from the other ships and they had no special rendezvous. Other ships than the Acme coming into San Francisco are comparatively free from typhoid.

In order to find out whether any other ships sailing to and from Humboldt Bay and taking water there were troubled with typhoid, a number of ships accessibse in San Franciseo Bay were risited and the owners of other vessels were interviewed. In no instance had 
there been recent cases of typhoid fever on board the ships. On six ships sniling to Humboldt Bay we asked whether the men knew of any vessels on which there had been typhoid, and on four of the six the reply was made that the Acme had had trouble with the discase. No other ships were mentioned as having typhoid. 1)r. S. 13. Foster, the officer representing the United States Public Health and Marine-IIospital Sirevice at Eurcka, reported that no cases of typhoid had (ome uncler his care since Janunry, 1908.

The evidence alrealy presented gave ground for a strong suspicion that the series of typhoid cases among the erew of the Arme arose from a focus on board the ship. Bvery effort was then made to detect the sourec. by examination of individuals who might be enriers. It was impossible to lay the hlame on any one cook or waiter as these men had been changed at short intervals during the series of cases. $A$ similar situation existed with regard to the seamen and firemen. With the exeeption of the eaptain (G. O.), the first mate (J. H.), the ehief engincer (L. P.), and the winch-driver (II. O.). no members of the ship's comprany at the time of beginning the investigation had been aboard for any considerable period. When the first visit to the Arme was male, slye was in dry-rlock and all the men lad been ilischarged excent the four mentioned above. Of these only the captain (G. O.) and the winch-driver (H. O.) had been aboard during the entire serie's of cases. The enptain had never had typhoid. The winch-driver had had the discase four years before, but he had been examined in 1)ecomber, 1911, by the city bacteriologist of San Franciseo and his stools had been found free from typhoid bacilli. The first mate had not had typhoid. He had been aboard for a year, and two years previously he had been in service on the same ship. The ohief engineer hat beon on the Arme sines April $6,1910$. and had been infected with typhoid on the ship in February, 1911.

The first laboratory investigation consisted of examinations of blood, feees and urine from the eaptain (G. O.), the first mate (J. H.), and the chief engineer (L. P.). Specimens were taken at the ship on December 30 , and Junuary 3 , and additional samples from L. P. on January 16. Fxamination of the blood showed a positive Widal reaction for the engineer (L. P.). The other blood examinations were negative. Fxaminations of the urine and fees of each of the three men failed to revent typhoid bacilli.

Shortly after the specimens from the captain; first mate, and chief engineer had been found to be free from typhoid bacilli, it was learned that two seamen of the Acme had just come down with typhoid and were under the care of the United States Marine Hospital in I os Angeles. It was decided to begin the investigution mew by making a thorough investigntion of hospital records and of the names and dates on back pay-rolls of ship-owners; and also by interviewing as many of the early patients of the typhoid series from the Acme as could be renched. The records of the United States Marine Hospitals in San Francisco and Los Angeles were of great value, and we are greatly indebted to
Surgeons Jumes M. Gassaway and S. D. Brooks for placing hospital records at our disposal. We were fortunate in being able to find and interview four of the early patients, V. B., I. O., l. P., and $0 . K$. 'The results of the searching of records and interviewing of former patients enablecl us to secure the information shown on the rhart illustrinting this article. All the evidence tended to indicate thint the winch-driver (II. O.) was responsible for the series ol cases on the Acme and also for the single case received by the Marine Howpital since Innury, 1908, from the steamer Arctir. For the sake of hrevity and clearness the ehart has been mate to show the history of $H$. O., the winch-alriver, from the time of his taking service on the steamer Aretic to the time when our investigation was completed. The chart shows also the lengrth of his stay aboind ench ship on which he served, nuel indicites by initinls all typhoid pationts known to have aome from these ships into hospitals and wives the dates of their stay umiler treatment. $A$ study of the dates shows that all the cases received theip infertion while on board ship with 11.0 . 'l'he diagram shows also that putients from the Acme were cared for in three cities, Sin Francisco, Oakland

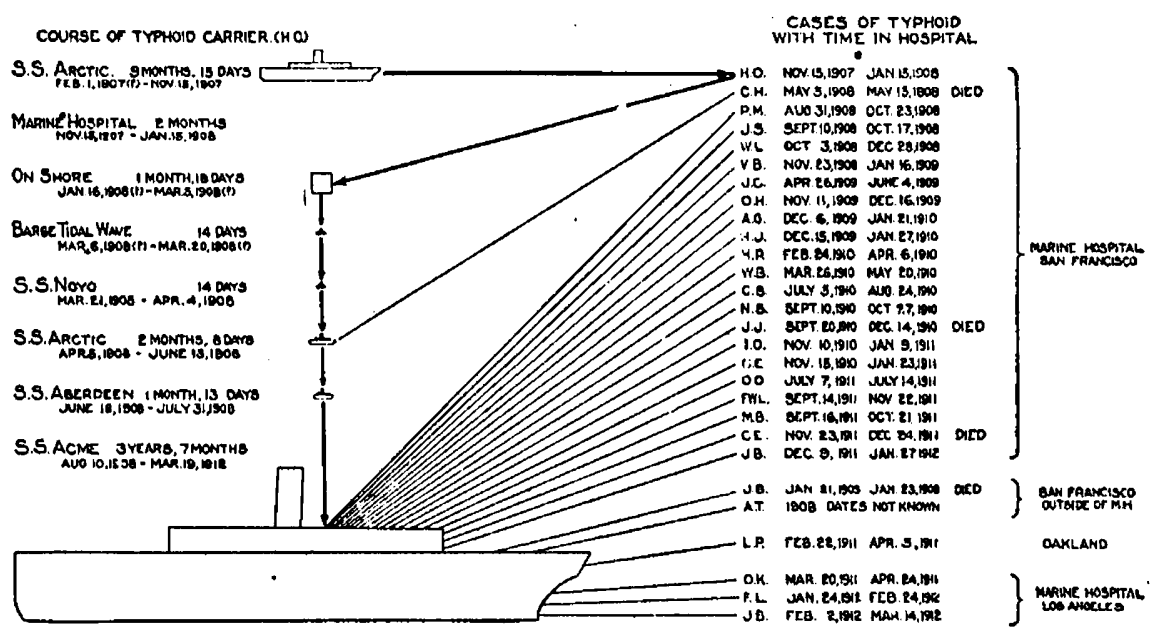

Chart showlug berlods of servies of a typhold enrler on slx shlps and resulting chses

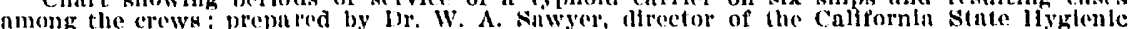

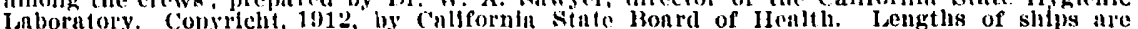
proportional to length of stay of carrler on bind shlps. and Los Angeles. That there were other undiscovered eases can be little doubted. In fnct, one victim, J. F., who was reported by ono of the erew, was omitted from the statistics because the diagnosis could not be confirmed by other evidence. The cuses were not limited to the' seamen. L. I'. was (hief engineer, and J. 13., who died in the German Hospital in San Francisco, was first mate.

It will be notieed that during the stay of H. O. on the Acme, covering a period of forty-three months, there were twenty-six cases. During his perion of service next in length (two and one:fourth months on the Arctic) one case occurred. In all there were twenty-seven cuses of typhoid fever, four of which were fatal. Of the patients twenty-one were in the United States Marine Hospital in Sun Francisco, and three of them died, making the mortulity 14.3 per cent. During the period beginning with H. O.'s return to work after his illness and ending Fel. 22, 1912, sixty-three typhoid patients were admitted into the Marine Hospital in Sun Frunciseo from all other ships entering Sin Francisco Bay, including the river boats, foreign ships and government boats. (of these sixty-three patients six died, showing a mortality 
of 9.5 per cent. The cases traceable to the carrier, H. O., were one-fourth of all the typhoid sases arlmitted and were responsible for one-third of the resulting denths. Under the care of the Marine Hospital in Los Angeles during the same perjod there were three cases from the Acme and fourteen enses from other ships. All of the seventeen pationts recovered. All the cases which could be eollected and confirmed showed that there had been twenty-seven cases traceable to $H$. $O$. and that four of the patients had died. This gives a mortality of $1+.8$ per cent., which suggests that the infection being distributed by $\mathrm{H}$. 0 . was more virulent than the average strain of typlioid.

The evirlence collected strengthened all previous suspicions that the infections came from a carrier on board the Acme, and special suspicion fell on H. O. It was decided to make thorough laboratory examination of

TABLE 1.-AGGLUTINATION TIESTS ON TIREE SUSPIDCS AND TWO CONTROLS

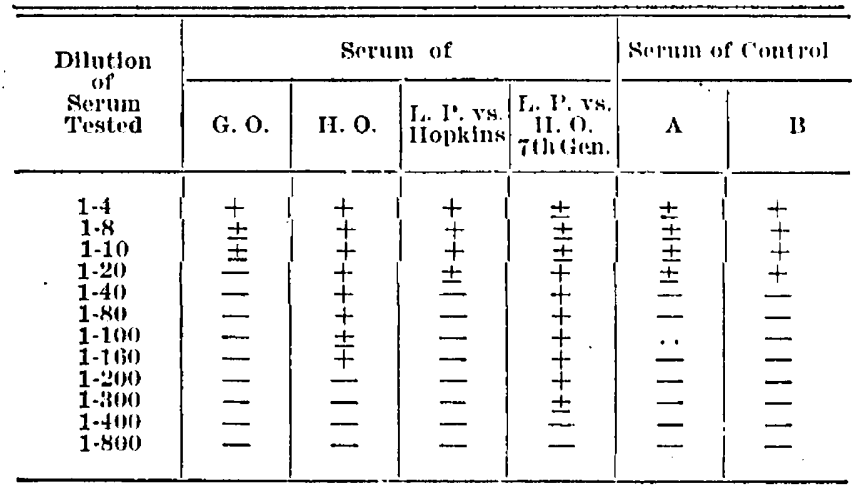

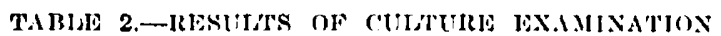

\begin{tabular}{|c|c|c|c|c|c|c|}
\hline \multirow{2}{*}{ Ninme } & \multirow{2}{*}{ Spec. } & \multirow{2}{*}{$\begin{array}{l}\text { No. of } \\
\text { Findo } \\
\text { Plates }\end{array}$} & \multirow{2}{*}{$\begin{array}{c}\text { Colontes } \\
\text { Suspleious } \\
\text { in } 48 \text { Ilours }\end{array}$} & \multirow{2}{*}{$\begin{array}{l}\text { Colonles } \\
\text { on } \\
\text { Irussell's } \\
\text { Med. }\end{array}$} & \multicolumn{2}{|c|}{$\begin{array}{l}\text { Irenction on Jus- } \\
\text { sill's Misd. After } \\
2 \text { to } 14 \text { Inys }\end{array}$} \\
\hline & & & & & l'ositlve & Nogutlve \\
\hline 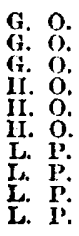 & $\begin{array}{l}\text { Jrine } \\
\text { Feces } \\
\text { Feces } \\
\text { Vrine } \\
\text { Urine } \\
\text { Feces } \\
\text { Urine } \\
\text { Fecis } \\
\text { - Feces } \\
\text { Feces }\end{array}$ & $\begin{array}{r}0 \\
12 \\
11 \\
0 \\
6 \\
12 \\
6 \\
18 \\
0 \\
0\end{array}$ & $\begin{array}{l}\text { None } \\
\text { low } \\
\text { rew } \\
\text { low } \\
\text { fow } \\
\text { very mnny } \\
\text { Very few } \\
\text { Very fow } \\
\text { Vory few } \\
\text { Vory fow }\end{array}$ & $\begin{array}{r}0 \\
14 \\
25 \\
5 \\
5 \\
5 \\
107 \\
20 \\
10 \\
5 \\
5\end{array}$ & $\begin{array}{r}0 \\
0 \\
0 \\
0 \\
0 \\
\mathbf{5} 5 \\
0 \\
0 \\
0 \\
0\end{array}$ & $\begin{array}{r}0 \\
14 \\
25 \\
5 \\
5 \\
5 \\
52 \\
20 \\
10 \\
5 \\
5\end{array}$ \\
\hline
\end{tabular}

material from all persons under slightest suspicion and to begin with the chicf engineer (L. J.), the captain (G. O.), and the winch-driver (H. O.). 'The plan jncluded keeping each man under investigation in a hospital for at least twenty-lour hours. This would insure that the specimens were bona fide and properly taken. The A. W. Beadle Co., owners of the Acme, generously met the expense of keoping the men in the lioosevelt Hospital in Berkeloy. On March 2 , the $1 \mathrm{cme}$ came into port at Oakland and the captain (G. O.) and winchdriver ( $H$. O.) eame to the hospital. Specimens of blood, urine, and feces were obtained from the two men during theil stay of thirty hours. On March 10 the chief enginecr (L. P.) reported for olsservation. Similar specimens were obtained from him during the following twenty-four hours. All three of the men we:e given fluidextract of cascara on admission to the hospital and Ipsom salts the next morning.
The results of agglutination tests performed on the blood samples from G. O., H. O., I. P., and two nommal individuals who had nover had typhoid fever (A. and B.) are given in the first table. The test was male macroseopically and the serum was allowed to act for twentyfour hours in the specified dilutions on bouillon cultures of the Ilopkins strain of typhoid except in one of the tests of the serum of $I_{\text {d. }} \mathrm{P}$. In that case the sixtl reneration of a typhoid culture isolated from the stool of H. O. was used. It will be noticed that the serum of I. P. who had heen infected on board the Acme had much greater agglutinating power for the bacilli from 17. O. than for the standard laboratory culture. In Table 1 positive results are indirated by the sign + , negative by the sign - and partal (showing clumps and cloudy fluid) by the sign \pm .

The specimens of feces and wine were plated on Findo medium. Suspicious colonies were transferred to IRussell's double sugar agrar. 'Those showing reactions claracteristic of typhoid bacilli were submitted in bouilon culture to macroscopic agglutination tests with antityploid serum. 'The results of the first part of these examinations are shown in 'lable 2.

In the second table it will be seen that fifty-five of the cultures isolated from the feces of $\mathrm{H}$. O. gave the renction characteristic of trphoid bacilli on Russell's medium. 'Twenty-six of these were planted on broth, and this third generation of the organisms on artificial mediums was tested with antityphoid serum. 'The macroscopic ngerlutination test was positive in twentyfour hours in all cases in dilutions of one to twenty but only partinl in dilutions of one to fifty. In glueose broth these cultures all produced acicl but no gas. Seven of these cultures from H. O., together with controls of known typhoid and colon bacilli, were tested for motility. for indol production, for ncid and gas formation in various sugar media (dextrose, lactose, mannit), for production of color-change in neutral red agar, for congulation of milk, and for liquefaction of gelatin. The cultural characteristics of the seven organisms from H. O. were identical with those of the typhoid bacillus. 'The failure to be completely agrolutinated by antityphoid serum in dilution of one to fifty was accredited to the power which newly jsolated cultures have of resisting agglutinins. This explanation was confurmed after some of the cultures lad been transplanted through the eleventh generation in the course of two weeks. The strains from II. O. then equaled the Hopkins strain in agglutinability. Both struins gave complete agglutination at one to 4,000 and partial results up to one to 500,000 . One of the H. O. cultures even showed evidence of elumping at onc to $1,000,000$.

'The proof that H. O. was a carrier was now considered complete and the findings were reported to the secretury of the State Board of IIealth for executive action. What to do. with. H. O., now that he was known to be a constant source of danger, became a serions problem. He was an able-bodied man of 36 . He had not been sick since recovering from typhoid in January, 1908, and he complained of no symptoms. He ran the winch on the lorward end of the Acme and cared for the lamps and gear's when the ship was at sea.

At a conference between health officials and a representative of the owners of the Acme, it was decided, on March 19, 1912, that tiis carrier should be taken off the Acme and an attempt should be macle to rid him of his infection through appropriate treatment. Surgeon James il. Gassandy made this possible by offering to 
take him into the United States Marine Hospital in San Francisco for study and treatment. Accordingly the Secretary of the State Board of Health visited the Acme und notified $\mathrm{H}$. O. that he would be transferred to the Marine Hospital and would be placed under quarantine there. When $H$. $O$. was informed of the dunger of his presence to others, he showed deep conrem and voluntarily gave up his work and entered the Joepital.

$\Lambda$ consideration of the facts revenled by the invertigation of the source of typhoid fever on the Acme leads to the following olservations:

1. A carrier may be of great danger to others, even when not necupied in the preparation or handling of food. Conditions on shipboard may be specially favornble to the transference of infection, as witnessed by the occurrence of twenty-six cases within three and a half years on a ship carrying twenty-one men.

2. In examinations of cultures freshly isolated from materials suspected of containing typhoid bacilli, newative agglutination tests with the usual dilutions of serum should not be aceepted without culturnl confirmation. The well-known power of freshly isolated cultures to resist agglutinins was strikingly jllustrated.

3. Emplasis is given by this investigation to the point which others have made that typhoid patients should not be unconditionally dismissed by physicians unless their feces and urine have been examined and found to be free from typhoid bacilli. If the staff of the Marine Hospital in San. Francisco hed discovered typhoid bacilli in the stools of their patient, H. O., in january, 1908, and had in some way prevented his spreading typhoid among sailors, this one hospital would have snvel for itself the expense of treating twenty-one typhoid patients, and four clenths would have been prevented.

\section{THE VALTE OF 'THE WIIDAL REACTION IN TIIE IDETECTION OF 'IYPHOID CARLIERS}

EDWARD B. BIGEIOW, M.D.

Assistant Bactrolologist, Bourd of IIealth WOHCESTER, MASS.

In a previous communication ${ }^{1}$ I have saic that most carriers of typhoid bacilli lave a persistent positive Widal agglutimntion reaction and suggested that this fact should be taken advantage of to trace the source, and if possible anticipate a typhoid epidemic. By this means in Worcester, in 1910. one carrier was discovered who initiated an epidemic of 213 cases of typloid, and in 1909 , the probable source of two other smaller epidenies was brought to light. To show the efficiency of this procedure the cases of two more typhoid carriers are now bricfly reported from our 1911 experience.

1. Between August 1 and September 27, five cases of typhoid were reported to the bourd of health on one milk route. The dairyman, the producer of about 60 quarts of milk duily, wis also his own ilistributor. Specimens of blood were obtained from all persons on the dairy farm. One only, that of the dairyman himself, gave a positive Widal agglutination. $\mathrm{He}$ was 51 years of age and said that he fiad had typhoid twice, once when about 10 years of age and again about eight years ago, since which time his general health had been good. His urine and feces were exmmined. The feces contained typhoid

1. Bigelow: The JuUnal A. M. A., Oet. 28, 1011, p. 1418. bacilli. On the evidence of the positive Widal he had been prohibited from distributing milk. Nine more cases of typhois were reported developing anong his former customers in the next two weeks and none later.

2. On the report to the board of health of the denth of one person and the illness of two other relatives in the neighboring louse from typloin, an investigntion was instituted. In the family of the dead victim five months previously there had been one other death apparently from preumonia. In this same family was a man who had had an attack of typhoid when in another state, eighteen months previously, followed by necrosis and alsecss formation about the stermum. In spite of an operation a year ago he still had two small pus-rlischarging sinuses over the sternum leading down to the bone bare of periosteum. II is blond gave a positive Widal reaetion. On three different examinations his urine and feces were found negative for typhoid bacilli, but the pus from the sinuses over the sternum was positive on each of these orcasions. 'The intermediary agent from the carrice to the three syuchronous cases of typhoid fever secmed in this instance to have been fruit, which the. carricr gathered some days before the onset of their" attacks.

61 Pearl street.

\section{EXPERIMENTS WITH BISMUTH PASTES}

\section{F. MCKELVEY BELI, M.D. OTTAWA, CANADA}

1)uring the past two years I have used Beck's bismuth paste in a variety of conditions and with more or less favorable results.

It may be said a priori that bismuth paste is useful not solely in chronic conditions. Muny recent sinuses and sloughing wounds, etc., are quite amenable to this form of trentment.

The first series of cases were those of tubercular adenitis, twelve cases in all, ten cervical and two inguinal. In this condition, in which some of the glands are caseating or suppurating, it is almost impossible to keep a perfectly asejtic field during operntion and, cven when the glands have not broken down, the size of the cavity after their removal, often filled with blood as it is, encourages pus formation. It appenred that if this cavity were filled with bismuth paste before the last closing suture was inserted, suppuration would be prevented. This proved to be the ease. 'There was no pain after operation and the eavity filled with a perfectly clear, aseptic mixture of serum and liquefied petrolatum, the bismuth being precipitated. Unfortunately for the success of the experiment, in these cases the paste seems to do more than its luty, not only preventing pus formation, but, in addition, preventing the formation of healthy gramulations. The wound required to be opened and drained in the usual manner, but took much longer than usual to henl. In some of these wounds, which had filled with serous or seropurulent fluid, a stiteh was removed and bismutle paste injected. The wounds healed painlessly, but rather more slowly than those in which the other forms of drainage were employed. In one case in which henling had taken place quite promptly there was an opening through a small vesicle about every second week, and a small quantity of seropus was discharged; then healing woukd rendily take place agnin without further discharge. After this had happened three times it occurred to me that there might be some foreign body in the wound, and with a probe this could be felt 